\title{
Soil-gas radon/helium surveys in some neotectonic areas of NW Himalayan foothills, India
}

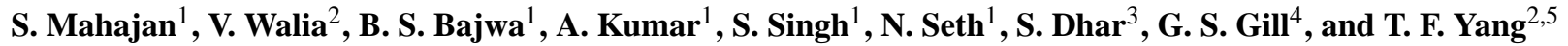 \\ ${ }^{1}$ Department of Physics, Guru Nanak Dev University, Amritsar-143005, India \\ ${ }^{2}$ National Center for Research on Earthquake Engineering, NARL, Taipei-106, Taiwan \\ ${ }^{3}$ Department of Geology, Government College, Dharamsala, Himachal Pradesh, India \\ ${ }^{4}$ Department of Geology, Punjab University, Chandigarh, India \\ ${ }^{5}$ Department of Geosciences, National Taiwan University, Taipei-106, Taiwan
}

Received: 4 December 2009 - Revised: 30 April 2010 - Accepted: 11 May 2010 - Published: 17 June 2010

\begin{abstract}
The present research is aimed at accessing the relationship between variation in the soil gases radon $\left({ }^{222} \mathrm{Rn}\right)$ and helium $\left({ }^{4} \mathrm{He}\right)$ and recently developed fissures and other neotectonic features in Nurpur and Nadha areas of the NW Himalayas, India. Two soil-gas surveys were conducted on/near known faults to reconfirm their position using soil gas technique and to check their present activity. During these surveys, soil-gas samples were collected along traverses crossing the observed structures. The data analysis reveals that the concentrations of radon and helium along the Dehar lineament and the longitudinal profile (Profile D) are very high compared to any other thrust/lineament of the Nurpur area. The Nadha area shows high values of radon and helium concentrations along/near the Himalayan Frontal Fault (HFF) as compared to the adjoining areas. This indicates the presence of some buried fault/fault zone running parallel to the HFF, not exposed to the surface and not delineated by satellite data but is geochemically active and might be tectonically active too. Hence, soil helium and radon gas patterns have been combined with morphological and geological observations to supply useful constraints for deformation of tectonic environments.
\end{abstract}

\section{Introduction}

Noble gases are excellent natural tracers for several geological features as they are chemically inert (Banwell and Parizek, 1988; Monnin and Seidel, 1991; Ciotoli et al., 1998; Segovia et al., 1999; Toutain et al., 1999; Fu et al., 2005; Walia et al., 2006, 2009a, 2009b). Spatial variations of noble

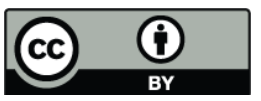

Correspondence to: V. Walia (vivekwalia@ rediffmail.com) gases like radon $\left({ }^{222} \mathrm{Rn}\right)$ and helium $\left({ }^{4} \mathrm{He}\right)$ are widely applied in studies to locate buried/blind faults and in seismic monitoring activities (Yang et al., 2005, 2006). Both radon and helium are products of the uranium decay series. Several researchers have made efforts previously to elucidate the role of these gases in delineating active faults and their relationship to seismically active areas.

The Himalayan orogeny is a byproduct of the continentto-continent collision due to the convergent movement of the Indian plate towards Eurasian plate. A series of major thrust planes; the Main Central Thrust (MCT), the Main Boundary Thrust (MBT) and the Main Frontal Thrust (MFT)/Himalayan Frontal Fault (HFF) have been formed as a result of these processes (Gansser, 1964). The continuous northward movement of the Indian plate is observed in the forms of seismic activity which leads to development of neotectonics along these thrust planes. Neotectonic features are manifested in the morphology of the landscape developed as a result of seismic activity that took place in the recent past. Neotectonic movements have been inferred from the variety of geological and geomorphic features of various parts of the Himalayas (Narula et al., 1989; Valdiya, 2003)

The Nurpur and adjoining areas in the NW Himalayas are part of the foreland basin where neotectonic activities have been observed along the MBT via remote sensing data (Singh et al., 2006). Besides the longitudinal lineaments several transverse lineaments occur as faults and fractures trending normally or obliquely to the Himalayan trend. The various rock units in the study and adjoining area are cut across by transverse faults/lineaments. The transverse faults control the main structural pattern of the region in general (Mahajan and Kumar, 1994). The area under study and the adjoining area of Dharamshala are one of the most active earthquake zones in the Himalayan seismic belt and had experienced several destructive earthquakes in the 20th century namely

Published by Copernicus Publications on behalf of the European Geosciences Union. 


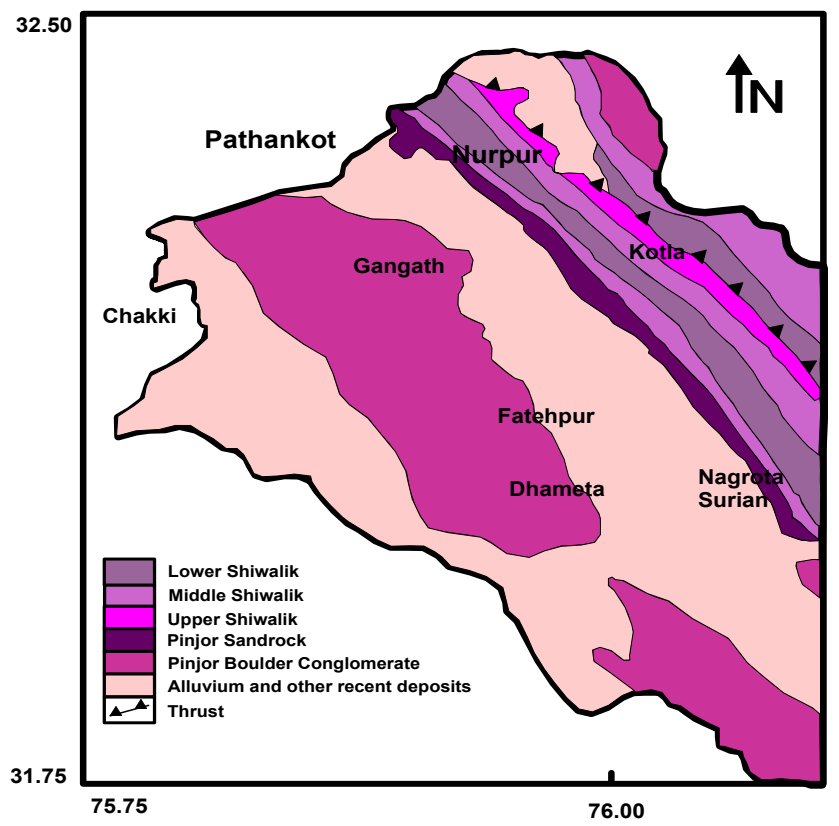

Fig. 1. Map of Nurpur and adjoining area showing geological divisions and the Jawalamukhi thrust crossing the area.

in $1905,1968,1978$, and 1986 with a magnitude of $8.6,4.5$, 5.0, and 5.5, respectively, on the Richter scale. The 1905 Kangra and the 1986 Dharamshala earthquakes are related to the Main Boundary Thrust and its subsidiary the Drini thrust trending in a north-west to south-east direction, while the 1978 Dharamshala earthquake is correlated with a transverse fault (Kumar and Mahajan, 2001).

Geologically Nurpur and its adjoining area in the district of Kangra (Himachal Pradesh) lies between $32.0^{\circ}-32.4^{\circ}$ North latitudes and $75.7^{\circ}-76.0^{\circ}$ East longitudes. The area represents a thick succession of lower, middle and upper $\mathrm{Si}$ walik sediments which is comprised mainly of sandstones, clays and boulder conglomerates, succeeded by recent alluvium towards the south (Fig. 1). It comprises dominantly of middle and upper Siwaliks which are separated by a regional thrust namely the Jawalamukhi Thrust. The area forms an integral part of the Frontal Folded belt of the Himalayas and is considered to be active seismically (Mahajan and Kumar, 1994). A study of high resolution satellite data shows a complex pattern in the region with a number of lineaments being identified which are either parallel to the MBT or transverse to it. Apart from the longitudinal thrust plane, the region is traversed by transverse lineaments/faults viz. the Dehar lineament and Gaj lineament (Fig. 3). The presence of these important structural elements/planes has made the study area tectonically interesting. A similar structural configuration of longitudinal thrust/fault systems and transverse lineaments has been observed in the adjoining Dharamshala area of the Kangra district (Dhar et al., 2002, Walia et al., 2008).
Another area named Nadha is located NE of Chandigarh city near Panchkula along the Ghaggar river in the vicinity of the HFF (Fig. 2). Multiple phased neotectonic features have been reported in geological and geomorphic studies of the area (Kumar et al., 2004). The area marks the southernmost fringe of the Himalaya, where the un-deformed succession of the Indo-Gangetic Plains is separated from the detached, complex folded-faulted Upper Siwalik Hills comprising molassic sediments of lower Pliocene-early Pleistocene age. The boundary is well-defined by the HFF system. The Ghaggar river, which is the major drainage in this area flows SSW, cuts transversely the NNW trending Upper Siwalik Hills before debouching into the plains. The most prominent deformation along the HFF was observed along the western banks of river Ghaggar (Fig. 2), northeast of Chandigarh (Nakata, 1989). The remote-sensing data and field studies have shown the existence of active fault traces in the foothill zone, with the average length varying from 2 to $10 \mathrm{~km}$ and strike from $\mathrm{N} 25 \mathrm{~W}-\mathrm{S} 25 \mathrm{E}$ to N15E-S15W. The digression in the strike is due to the sinuous nature of the mountain-front. The surface expressions of the faults are marked by a discontinuous drainage pattern. The folding of Siwalik bedrock north of the HFF and the occurrence of large historical earthquakes that apparently have not broken the surface, have been the basis to suggest that the HFF is a blind thrust (Stein and Yeats, 1989; Yeats et al., 1992; Yeats and Thakur, 1998). Lack of apparent surface expression of the HFF has also led some workers to believe that the HFF is concealed by Quaternary deposits or eroded (Raiverman et al., 1993; Valdiya, 2003).

To determine the relationship between the recently developed fissures and other neotectonic features reported in the study areas with soil gas radon/helium variations, surveys were conducted. Effort was made to collect soil gas samples on/near already reported various faults (Kumar et al., 2004; Singh et al., 2006) to reconfirm their position using this soil gas technique and to give an indication of their present activity levels. Soil gas samples were also collected in areas where no such faults were reported.

\section{Sampling procedure}

To carry out the soil gas investigations, transverse profile surveys have been conducted across the probable fault locations. During these surveys soil-gas samples were collected along/traverses crossing the observed structures and were analyzed for radon and helium gases.

In soils, gases are commonly sampled at depths of 0.7 $1.0 \mathrm{~m}$ with steel probes. For this a hollow steel probe of $3 \mathrm{~cm}$ diameter and $130 \mathrm{~cm}$ long is selected and a disposable sharp awl attached at the bottom of the steel probe, which makes the steel probe suitable for drilling into the soil and prevents soil from blocking the probe. This steel probe is placed into the ground at the depth of about $0.8-1.0 \mathrm{~m}$ by pounding using a hammer and drive-in-head. A thin solid billet (punching wire) is used to displace the tip and allows the lower end 


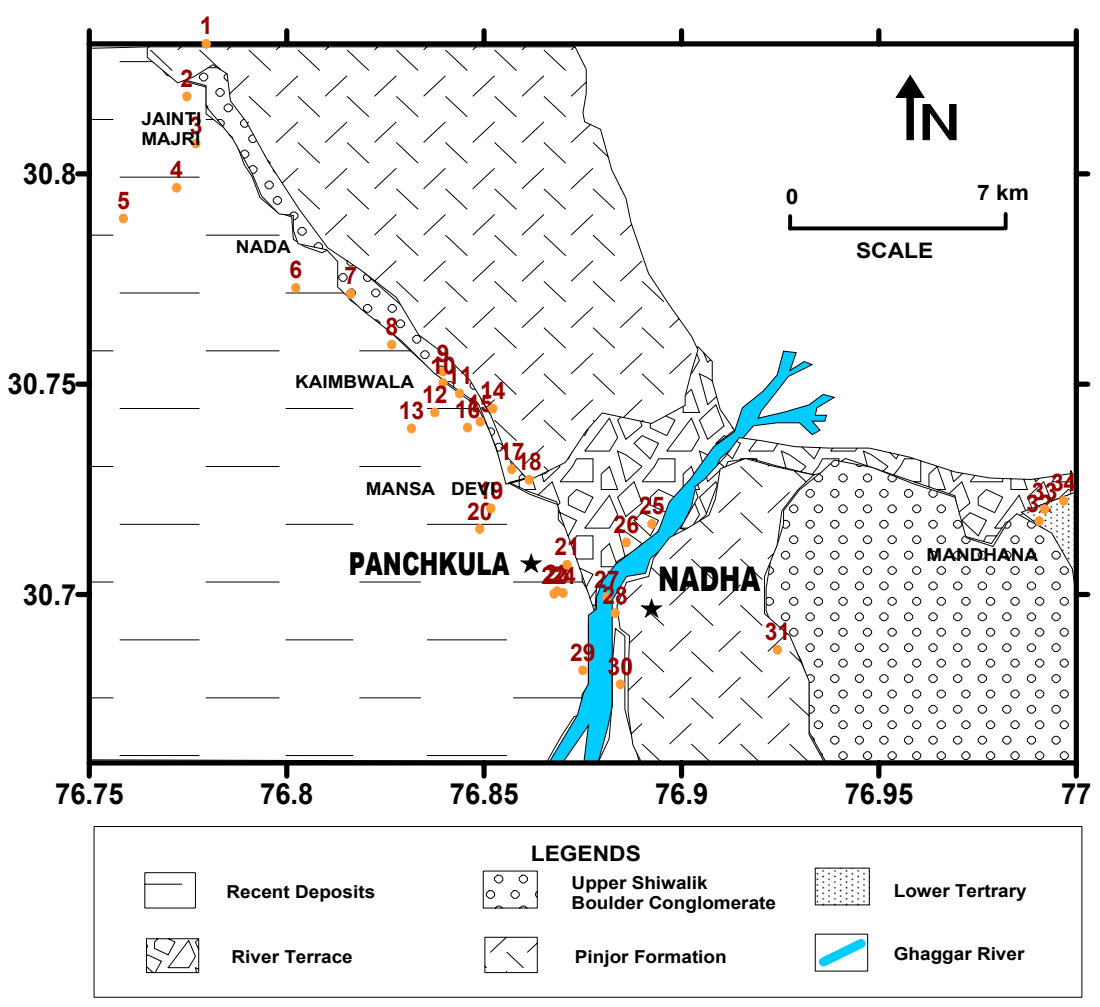

Fig. 2. Map of Nadha and adjoining areas showing the geology of the study area and locations of soil gas samples (marked 1-34) collected.

of the probe to be in contact with soil-surface at the required depth. A hand-pump, pumping through a specially designed rubber tube (with two filters: one for dust and another one for moisture) was connected with the hollow steel probe, and used to collect gas into a sample bag (Walia et al., 2009a). If the flux is strong enough then the hand pump can be replaced by an Alpha-pump (an automatic pump having pumping rate of $11 / \mathrm{min}$ ) to collect soil-gas in the pre-evacuated sample bags having capacities of 11 or 31 , for helium and radon analysis, respectively (Walia et al., 2005). Before collecting the soil gas in sample bags the tube and the probe must be flushed for air, which might be present, by pumping it for approximately $1 \mathrm{~min}$.

Sample bags used for collecting soil-gas are Tedlar standard sample bags (manufactured by SKC) which utilize a lightweight, patented compact single fitting of inert polypropylene that combines the hose/valve and the septum holder (for 1 liter bags). For 31 bags, there are two fittings of inert polypropylene that combine the hose/valve and the septum holder which allow the sample bag to be used in a closed circuit for radon analysis.

The samples collected for radon analysis are immediately connected to a RTM 2100 (SARAD, Germany) radon detector using a closed circuit for 50-60 min until radon has reached a steady state. The pump installed inside the device circulates the air through the sample bag and the radon measurement ionization chamber. A two stage filter keeps out radon and thoron progeny, only ${ }^{222} \mathrm{Rn}$ and ${ }^{220} \mathrm{Rn}$ gases can pass through the chamber inlet. A sufficiently large time interval, i.e., $10 \mathrm{~min}$ has been selected to obtain a usable countsum as suggested.

The sniffing probe technique is used for helium analysis in soil-gas from collected sampling bags using a helium leak detector ASM 100 HDS (Alcatel, France) in the laboratory. It comprises of a helium gas analyzer with internal pumping system. The main component of the helium leak detector is a spectro-cell (with a sensitivity of $3 \times 10^{-4} \mathrm{~A} / \mathrm{mbar}$ ) which acts as a mass spectrometer. Helium ion analysis is based on the partial pressure of helium in the system. It is calibrated and a logarithmic scale is used to display the helium concentration in ppm. The whole operation is fully automatic and helium values from 0.1 to $10^{6} \mathrm{ppm}(100 \%)$ can be measured.

\section{Results and discussion}

\subsection{Soil gas profiling in Nurpur area}

Neotectonic activities controlled along numerous lineaments/faults in the Nurpur region have resulted in contemporary morphological adjustments including drainage shifts and the development of fluvial deposits along a preferred orientation, and the recurrence of slope failure along the main structural line and their offshoots (Dhar et al., 2003; Shah and Pal, 1991). With an aim of finding the relationship between these neotectonic activities and soil gas radon/helium variations and also to better understand the tectonic behavior 

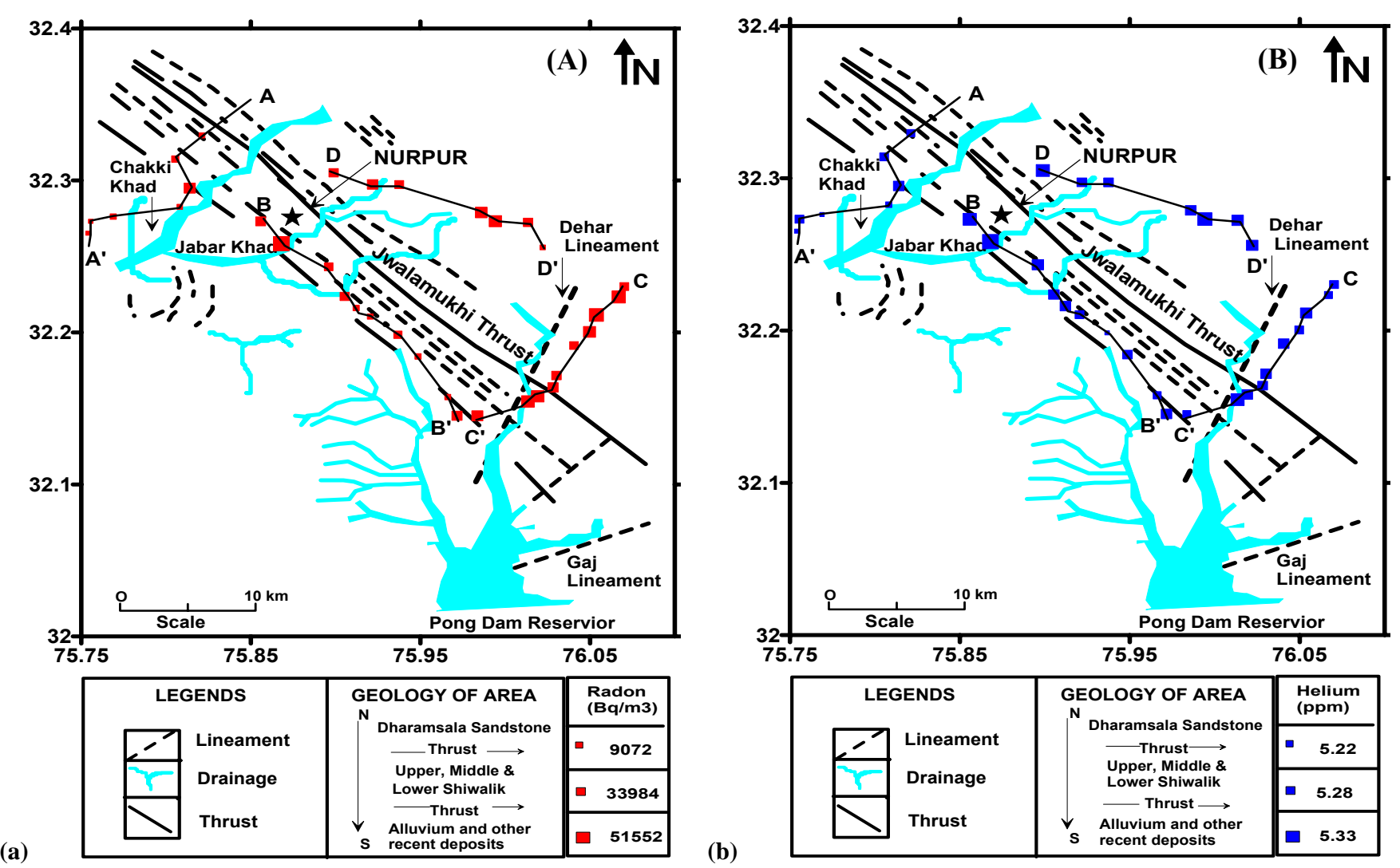

Fig. 3. Map of Nurpur and adjoining areas in the present study showing tectonic features (thrust, fractures, lineaments), drainage pattern (adapted from Singh et al., 2006) and the profile wise (A, B, C, and D) variation in

(a) radon concentration. The size of solid red rectangles corresponds to radon concentration varying from 9 to $53 \mathrm{kBq} / \mathrm{m}^{3}$.

(b) helium concentration. The size of solid blue rectangles corresponds to helium concentration varying from 5.22 to 5.33 ppm.

of thrusts, lineaments present in the study area, a survey was conducted to ascertain the spatial variation of soil gas during a period of stable meteorological conditions. About thirty-five soil gas samples were collected and analyzed for radon and helium. One earlier survey carried out by Singh et al. (2006) using plastic track detectors (LR-115) had shown the geological significance of soil gas radon in this area. A tectonic/lineament map was prepared by the authors using NRSA satellite data (1:50000, Toposheets No. 43P/15, 43P/16, 52D/4, LISS-III). This map has been modified in the present study to generate radon and helium anomaly maps showing the spatial variation of these gases along four different profiles (Profiles A, B, C and D) in the area (Fig. 3).

The sample locations are marked in ascending order from north to south (Fig. 3) e.g. Profile A starts with A (A1) and ends with $\mathrm{A}^{\prime}$ (A7), similarly for Profiles $\mathrm{B}, \mathrm{C}$ and $\mathrm{D}$. The value of radon in Profile A varies from $9 \mathrm{kBq} / \mathrm{m}^{3}$ (A7) to $34 \mathrm{kBq} / \mathrm{m}^{3}$ (A3) with an average value of $16 \mathrm{kBq} / \mathrm{m}^{3}$ and that of helium varies from $5.2 \mathrm{ppm}$ (A5, A7) to $5.27 \mathrm{ppm}$ (A3) with an average of $5.24 \mathrm{ppm}$. Samples locations A5, A6 and A7 were taken as background samples thus indicating relatively low values both of radon and helium. The sample $\mathrm{A} 3$ is located on the intersection of thrust and drainage (locally known as khad), and shows the highest value for radon $\left(34 \mathrm{kBq} / \mathrm{m}^{3}\right)$ and helium $(5.27 \mathrm{ppm})$. A1 and A2 although located very near to lineaments do not show anomalous values of either of the gases. This shows that not all the lineaments are geochemically active. Ten sampling locations in Profile B are taken longitudinal to the major thrust in the study area i.e., Jawalamukhi thrust. Radon concentration ranges from $14 \mathrm{kBq} / \mathrm{m}^{3}$ (B6) to $52 \mathrm{kBq} / \mathrm{m}^{3}$ (B2) and helium shows variation from $5.2 \mathrm{ppm}$ (B7) to $5.33 \mathrm{ppm}$ (B2). The average radon and helium values recorded along this profile are $21 \mathrm{kBq} / \mathrm{m}^{3}$ and $5.27 \mathrm{ppm}$, respectively. Higher concentration of both radon and helium at location B2 might be due to the fact that the sample was collected very near to the intersection of a drain passing through the area and the Jawalamukhi thrust, thus creating a pathway for deep gas sources. Most of the samples in Profile B are collected very near to the thrust but the average radon concentration for this profile is $21 \mathrm{kBq} / \mathrm{m}^{3}$ which is comparatively lower than Profile $\mathrm{C}$ and profile $\mathrm{D}$. This indicates that the thrust/lineament along Profile $\mathrm{B}$ is rather geochemically inactive and might be tectonically inactive too. A similar trend is observed in this zone by Singh et al. (2006) using a passive measurement technique. 
Profile $\mathrm{C}$, which is taken along the transverse Dehar Lineament, one of the major lineaments in the study area, shows a variation in radon concentration from $24 \mathrm{kBq} / \mathrm{m}^{3}$ (C5) to $46 \mathrm{kBq} / \mathrm{m}^{3}$ (C3) with an average of $35 \mathrm{kBq} / \mathrm{m}^{3}$. Helium varies from $5.24 \mathrm{ppm}$ to $5.3 \mathrm{ppm}$ with an average of $5.26 \mathrm{ppm}$. The comparatively higher average values of both radon and helium in Profile C indicate that the Dehar lineament is still tectonically active. The Dehar Khad-stream follows the transverse Dehar lineament which as per the results of soil gas seems to be active. Another longitudinal profile, profile $\mathrm{D}$ with seven sampling locations, is taken parallel to, but away from the thrust (Jawalamukhi thrust). The radon in this profile varies from $13-39 \mathrm{kBq} / \mathrm{m}^{3}$ while helium lies within the range 5.26-5.31 ppm. Although remote sensing data do not reveal the presence of any lineament/fault near Profile $\mathrm{D}$, comparatively higher average values of both radon $\left(31 \mathrm{kBq} / \mathrm{m}^{3}\right)$ and helium $(5.28 \mathrm{ppm})$ may well indicate the presence of some buried active fault in that zone which is not exposed at the surface.

It can be observed from the soil gas data that the concentrations of radon and helium along the transverse Dehar lineament (Profile C) and the longitudinal profile (Profile D) are very high compared to any other thrust/lineament in the area. These results on the whole hint at the role played by geomorphology and the underlying structure in the radon and helium abundance observed in the study area. The Dehar Khad (that follows the north-south transverse Dehar lineament) seems to be active, as suggested by the results of soil gas surveys. The stream initially shows some kind of parallelism to the regional Jawalamukhi thrust at the interphase of the lower Shiwalik sandstones and conglomeratic horizon of upper Shiwaliks. Subsequently, the stream turns through an approximate right angle to flow along the Dehar Lineament, repeatedly cutting across this other formation, and hints of river incision are evident along the contact zones of different horizons downstream (Figs. 1 and 3). The results further support the presence of the Dehar lineament which cuts across varied lithounits including sandstones, conglomerates, alluvium and other recent deposits. Since the abundances along the transverse lineament are high irrespective of the lithology, emanation of soil gases appear to be controlled by the same source through a deep seated fracture/fault in this zone. Higher values of soil gas radon and helium in the tectonically active adjoining Dharamsala region along transverse lineaments have also been reported (Dhar et al., 2002; Walia et al., 2008). Moreover, according to Srivastava et al. (1987) the seismicity related to the 1986 and 1987 earthquakes in the region are closely linked to the activity of the lineaments trending normal to the regional trend. Higher abundances of the soil gases radon and helium along transverse lineaments i.e. the Dehar lineament and its correlation with the structural elements becomes more significant when one keeps in view the seismic history of the area.

\subsection{Soil-gas profiling in Nadha and surrounding area}

The Nadha area is situated on the frontal part of the NNWSSE trending Siwalik Hills of the NW Himalayas (Kumar et al., 2004). It is separated in the north-west from the Chandigarh Siwalik Hills by the water gap drained by the Ghaggar River that originates in the southern slopes of the Lesser Himalayas (Fig. 2). Based on the geological and geomorphic studies in the area, Kumar et al. (2004) had reported some neotectonic features and associated these with movement of the HFF. To determine the relationship between the recently developed tectonic features reported in the study area with soil gas radon/helium variations, a survey was conducted; about thirty-four soil gas radon and helium samples were collected and analyzed. Figure 2 shows the geological map of the area in the present study and the sampling locations (marked 1-34). Effort was made to undertake transverse profiles in the area but the geographical conditions made it impossible to do so. Soil gas samples were therefore collected on/near various faults (marked "F", Fig. 4) already reported in literature, to reconfirm their position and to indicate their present activity. Soil gas samples were also collected in areas where no such faults were reported. The observed radon concentrations have been found in this study to vary from $4 \mathrm{kBq} / \mathrm{m}^{3}$ to $54 \mathrm{kBq} / \mathrm{m}^{3}$ with an average concentration of $17 \mathrm{kBq} / \mathrm{m}^{3}$ while that of helium varies from $5.24 \mathrm{ppm}$ to $5.38 \mathrm{ppm}$ with an average of $5.31 \mathrm{ppm}$. The values are comparable to those obtained in Nurpur and adjoining areas (Sect. 3.1) but quite low when compared to the Dharamsala areas (Walia et al., 2008) wherein soil gas samples are mainly collected along the MBT. This shows that the MBT of the Kangra region is geochemically/tectonically more active than the HFF of the Nadha region.

The soil gas data shows anomalous values of radon and helium along the locations which coincide with major tectonic structures in the study area (Fig. 4). Soil gas anomalies are clustered along two main faults of the frontal Himalaya designated as i) the Nahan Fault locally called the Jansu Fault (Kumar et al., 2004) in this region, ii) the HFF located between the Siwalik range and the Indo-Gangetic plain. Out of these two locations, the Jansu fault is older (but still active) than the Himalayan Frontal Fault in geological history. Three significant locations have been identified along the HFF:

- Near Jainti Majri (sample no. 5, radon $31 \mathrm{kBq} / \mathrm{m}^{3}$, helium $5.33 \mathrm{ppm}$ )

- Near Mansa Devi Temple (sample no. 13, radon $21 \mathrm{kBq} / \mathrm{m}^{3}$, helium $5.32 \mathrm{ppm}$ ).

- Near Kaimbala (sample no. 20, radon $49 \mathrm{kBq} / \mathrm{m}^{3}$, helium $5.27 \mathrm{ppm})$.

All these locations are near the foot of the Himalaya and marked by local faults. The surface features and geomorphic signatures such as river terraces, drainage diversions 

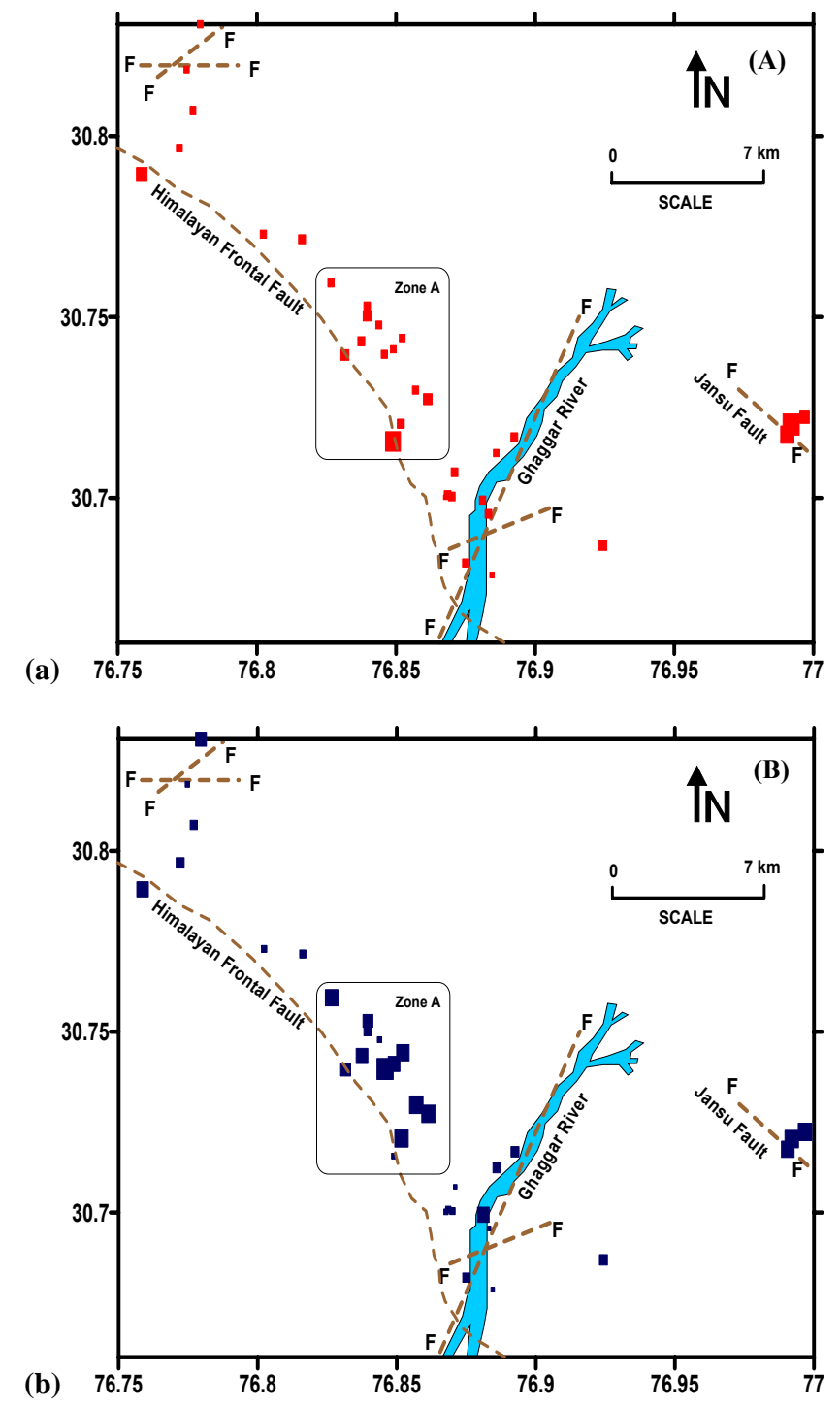

Fig. 4. Map of Nadha and adjoining areas in the present study showing tectonic features (faults), drainage pattern and the variation in radon concentration. The size of solid red rectangles corresponds to (a) radon concentration varying from 4 to $54 \mathrm{kBq} / \mathrm{m}^{3}$;

(b) helium concentration varying from 5.24 to $5.38 \mathrm{ppm}$.

and steep escarpments at these places indicate neotectonic activity in these areas (Kumar et al., 2004). The co-existent anomalously high values of both radon and helium near Mandhna (samples no. 32, 33, 34, radon $42,54,26 \mathrm{kBq} / \mathrm{m}^{3}$ and helium 5.34, 5.35, and $5.35 \mathrm{ppm}$, respectively) in the vicinity of the Jansu Fault (Fig. 4), indicate that this fault is geochemically active and might still be tectonically active.

Based on the present soil gas survey and data analysis, a probable fault Zone A (Fig. 4) is identified, showing high values of radon and helium concentrations compared to the adjoining areas. This indicates the presence of some buried fault/fault zone running parallel to the HFF not exposed to the surface and not delineated by satellite data but is geochemically active and might be tectonically active too.

\section{Conclusions}

Identification of active faults that have moved within the current tectonic regime, i.e. during the Holocene, helps in assessing whether or not tectonic movements are likely to occur and cause seismicity which is generally associated with these faults and hence assess to some extent the seismic risk in the surrounding region. In the Outer Himalaya or the foothills lying between the HFF in the south and the MBT in the north, numerous active faults and neotectonic features have been reported, which have generated major and great earthquakes.

Active faults, which are ubiquitously distributed in diversified domains of the Himalaya, are important in that they provide signatures of the ongoing post-collision tectonic activity. Active faults and seismic hazard evaluation in the tectonically active sub Himalaya is crucial because of the increasing urbanization and population growth in the foothills and in the adjacent plains. Distribution of active fault traces indicates frequent recurrence of large-magnitude earthquakes in this region.

As the study areas under present investigations, lie in the isoseismal zone of the 1905 Kangra and Chandigarh (AD 1500) earthquakes (Malik et al., 2003; Kumar and Mahajan, 2001; Bilham et al., 2005), with the availability of new datasets and our soil gas radon/helium observations, we cannot therefore rule out the possibility of a large magnitude earthquake occurring in the area in the near future. However, detailed investigation employing trench excavation surveys for palaeoseismological studies, including dating of past seismic events will also help in probabilistic earthquake hazard assessment of this region.

Soil helium and radon gas patterns, combined with morphological and geological observations, can supply useful constraints for deformation tectonic environments. The geochemical indicators such as radon and helium emissions serve as a tool for identifying the possible loci of future activation of faults. The co-existent spatial distribution of helium and radon shows better results than individual gas species used for this study. Some buried active faults (Profile D of Nurpur area and Zone A of Nadha area) which are not exposed at the surface and are not revealed by the satellite data can be delineated using this soil gas method. The rapidity and the low cost of the soil gas survey, make this method a powerful tool for geological investigation which can significantly contribute to seismic hazard assessment and to seismic forecasting when continuous monitoring is performed.

Acknowledgements. The authors acknowledge the National Science Council of Taiwan and Department of Science and Technology, New Delhi, India, for providing the financial supports. We are thankful to anonymous reviewers for their valuable suggestions for improvement of the manuscript. 
Edited by: R. Crockett

Reviewed by: G. Gillmore and another anonymous referee

\section{References}

Banwell, G. M. and Parizek, R. R.: Helium-4 and radon-222 concentrations in groundwater and soil gas as indicator of fault zones of facture concentration in unexposed rock, J. Geophys. Res., 93(B1), 355-366, 1988.

Bilham, R. and Ambraseys, N.: Apparent Himalayan slip deficit from the summation of seismic moments for Himalayan earthquakes, 1500-2000, Curr. Sci., 88, 1658-1663, 2005.

Ciotoli, G., Guerra, M., Lombardi, E., and Vittori, E.: Soil gas survey for tracing seismogenic faults: A case study in the Fucino basin, Central Italy, J. Geophys. Res., 103, 23781-23794, 1998.

Dhar, S., Randhawa, S. S., and Sood, R. K.: Lineament control and seismo-tectonic activity of the area around Dharamsala, Himalayan frontal zone, Himachal Pradesh, India, in: Geohazards in north-west Himalayas, Special Bulletin of IGA, PU, Chandigarh, 36, 28-29, 2003.

Dhar, S., Singh, S., Dogra, M., and Kochhar, N.: Geological significance of radon in eco-system of Dharamsala area, Himachal Pradesh, India, Natural Hazards and their Mitigations, Special Bulletin of IGA, PU, Chandigarh, 35(2), 139-147, 2002.

Fu, C. C., Yang, T. F., Walia, V., and Cheng, C-H.: Reconnaissance of soil gas composition over the buried fault and fracture zone in southern Taiwan, Geochem. J., 39, 427-439, 2005.

Gansser, A.: Geology of Himalayas, Interscience, New York, 1964.

Kumar, R., Gupta, L. N., and Gill, G. S.: Neotectonic structures and newly formed fissures of Nadah area, Himalayan foothills, Haryana, Special Bulletin of IGA, PU, Chandigarh, 37(1 and 2), 1-11, 2004.

Kumar, S. and Mahajan, A. K.: Seismotectonics of the Kangra region North Himalaya, Tectonophysics, 331(4), 359-371, 2001.

Raiverman, V., Srivastava, A. K., and Prasad, D. N.: On the foothill thrust of Northwestern Himalaya, Himal. Geol., 4(2), 237-256, 1993.

Nakata, T.: Active faults of the Himalaya of India and Nepal, Geol. S. Am., S., 232, 243-264, 1989.

Narula, P. L., Shome, S. K., and Nandy, D. R.: Neotectonic activity in the Himalayas, Geol. Surv. India, Spl. Publ., 26, 119-141, 1989.

Mahajan, A. K. and Kumar, S.: Linear features registered on the landset imagery and seismic activity in Dharamsala Palampur region (NW Himalayas), Geofizika, 11, 15-25, 1994.

Malik, J. N, Nakata, T., Philip, G., and Virdi, N. S.: Preliminary observations from a trench near Chandigarh, NW Himalaya and their bearing on active faulting, Curr. Sci. India, 85(12), 17931798, 2003.

Monnin, M. M. and Seidel, J. L.: Radon in soil-air and in groundwater related to the major geophysical events: a survey, Nucl. Instrum. Meth. A, 314(2), 316-330, 1992.

Segovia, N., Mena, M., Pena, P., Tamez, E., Seidel, J. L., Monnin, M., and Valdes, C.: Soil radon time series: surveys in seismic and volcanic areas, Radiat. Meas., 31, 307-312, 1999.
Shah, M. P. and Pal, D.: Landform and neotectonic studies around the Kangra Bisin, Himachal Pradesh using tm data, in: Mountain resource management and remote sensing, Surya publication Dehradun, 59-71, 1991.

Singh, S., Sharma, D. K., Dhar, S., and Randhawa, S. S.: Geological significance of soil gas radon: A case study of Nurpur area, district Kangra, Himachal Pradesh, India, Radiat. Meas., 41(4), 482-485, 2006.

Srivastava, H. N., Dube, R. K., and Raj, H.: Space and time variation in the seismicity pattern preceding to earthquake in the Himachal Pradesh, India, Tectonophys., 138, 67-77, 1987.

Stein, R. S. and. Yeats, R. S.: Hidden earthquakes, Sci. Am., 260(6), 48-57, 1989.

Toutain, J.-P. and Baubron, J. C.: Gas geochemistry and seismotectonics: a review, Tectonophys., 304, 1-27, 1999.

Valdiya, K. S: Reactivation of Himalayan frontal fault: Implications, Curr. Sci. India, 85, 1031-1040, 2003.

Walia, V., Su, T. C., Fu, C. C., and Yang, T. F.: Spatial variations of radon and helium concentration in soil gas across Shan-Chiao fault, Northern Taiwan, Radiat. Meas., 40, 513-516, 2005.

Walia, V., Mahajan, S., Kumar, A., Singh, S., Bajwa, B. S., Dhar, S., and Yang, T. F.: Fault delineation study using soil-gas method in Dharamsala area, NW Himalayas, India, Radiat. Meas., 43, S337-S342. 2008.

Walia, V., Virk, H. S., and Bajwa, B. S.: Radon precursory signals for some earthquakes of magnitude $>5$ occurred in $\mathrm{N}-\mathrm{W}$ Himalaya, Pure Appl. Geophys., 163, 711-721, 2006.

Walia, V., Yang, T. F., Hong, W. L., Lin, S. J., Fu, C. C., Wen, K. L., and Chen, C-H.: Geochemical variation of soil-gas composition for fault trace and earthquake precursory studies along the Hsincheng Fault in NW Taiwan, Appl. Radiat. Isotopes, 67, 1855-1863, 2009a.

Walia, V., Lin, S. J., Hong, W. L., Fu, C. C., Yang, T. F., Wen, K. L., and Chen, C-H.: Continuous temporal soil-gas composition variations for earthquake precursory studies along Hsincheng and Hsinhua faults in Taiwan, Radiat. Meas., 44, 934-939, $2009 \mathrm{~b}$.

Yang, T. F., Walia, V., Chyi, L. L., Fu, C. C., Chen, C-H., Liu, T. K., Song, S. R., Lee, C. Y., and Lee, M.: Variations of soil radon and thoron concentrations in a fault zone and prospective earthquakes in SW Taiwan, Radiat. Meas., 40, 496-502, 2005

Yang, T. F., Fu, C. C., Walia, V., Chen, C-H., Chyi, L. L., Liu, T. K., Song, S. R., Lee, M., Lin, C. W., and Lin, C. C.: Seismogeochemical variations in SW Taiwan: multi-parameter automatic gas monitoring results, Pure Appl. Geophys., 163, 693709, 2006.

Yeats, R. S. and Thakur, V. C.: Reassessment of earthquake hazard based on a fault-bend fold model of the Himalayan plateboundary fault, Curr. Sci. India, 74, 230-233, 1998.

Yeats, R. S., Nakata, T., Farah, A., Fort, M., Mirza, M. A., Pandey, M. R., and Stein, R. S.: The Himalayan frontal fault system, Annales Tectonicae, 6, suppl., 85-98, 1992. 